\title{
Differential expression of stem-cell-associated markers in human hair follicle epithelial cells
}

\author{
Keita Inoue ${ }^{1}$, Noriyuki Aoi ${ }^{1}$, Takahiro Sato ${ }^{2}$, Yuji Yamauchi ${ }^{2}$, Hirotaka Suga', Hitomi Eto', Harunosuke Kato ${ }^{1}$,
} Jun Araki $^{1}$ and Kotaro Yoshimura ${ }^{1}$

Several putative biomarkers have been suggested for identifying murine follicular stem cells; however, human hair follicles have a different pattern of biomarker expression, and follicular stem cell isolation methods have not been established. To isolate a stem cell population applicable to clinical settings, we conducted a comprehensive survey of the expression of stem-cell-associated (K15, CD200, CD34, and CD271) and other biomarkers (K1, K14, CD29, and CD49f) in immunohistological sections of the human epidermis and follicular outer root sheath (ORS). We also examined freshly isolated and cultured epidermal or follicular cells with single- and multicolor flow cytometry or immunocytochemistry. After sorting cells by CD200, CD34, and forward scatter (FSC) values (cell size), colony-forming assays were performed. We found that biomarkers were differentially expressed in the epidermis and ORS. Basal bulge cells were mainly $\mathrm{K} 15^{+} \mathrm{CD} 200^{+} \mathrm{CD}_{4}{ }^{-} \mathrm{CD} 271^{-}$, and suprabasal cells were $\mathrm{K} 15^{-} \mathrm{CD} 200^{+} \mathrm{CD} 34^{-} \mathrm{CD} 271^{-}$. We categorized follicular cells into nine subpopulations according to biomarker expression profiles. The $\mathrm{CD} 200^{+} \mathrm{CD} 34^{-}$bulge cells had much higher colony-forming abilities than the CD34 ${ }^{+}$population, and were divided into two subpopulations: $\mathrm{C} \mathrm{CD}_{200}{ }^{+} \mathrm{CD} 34^{-} \mathrm{FSC} \mathrm{C}^{\text {high }}$ (K15-rich, basal) and a CD200 ${ }^{+} \mathrm{CD} 34^{-} \mathrm{FSC}^{\text {low }}$ (K15-poor, suprabasal) population. The former formed fewer but larger-sized colonies than the latter. Follicular epithelial cell cultivation resulted in loss of K15, CD200, CD34, and CD271 expression, but maintenance of K14, CD29, and CD49f expression. We found that the bulge contained two populations with different localizations, cell sizes, and colony-forming abilities. We showed that K15, CD200, CD34, and CD271 were useful biomarkers for characterizing freshly isolated human follicular epithelial cells in diverse stages of differentiation.

Laboratory Investigation (2009) 89, 844-856; doi:10.1038/labinvest.2009.48; published online 8 June 2009

KEYWORDS: adult stem cells; colony formation; epidermis; flow cytometry; CD200; CD34

The mammalian hair follicle has a stem cell niche called the 'bulge' that acts as a reservoir of multipotent stem cells. The cells in the bulge give rise to all epithelial lineages of the skin, including epidermal and follicular keratinocytes, sebocytes, and hair; ${ }^{1-3}$ thus, they are referred to as 'hair follicle stem cells' or 'follicular stem cells'.

Although the precise location of the human bulge is obscure and different from that of rodents, it is thought to be located between the sebaceous gland duct and the attachment site of the arrector pili muscle (APM) in the outer root sheath (ORS). Among many reports that described various biomarkers for identifying hair follicle stem cells, ${ }^{4-11}$ the most convincing evidence was provided in recent reports suggesting that K15 and CD200 are biomarkers for human follicular stem cells that reside in the bulge. ${ }^{9,11,12}$ It had previously been shown that human and murine bulge cells specifically expressed K15. ${ }^{9}$ Skin and hair follicle analyses in K15/LacZ transgenic mice showed that K15 promoter activity was correlated with the differentiation level of epidermal and follicular keratinocytes. ${ }^{12}$ On the other hand, CD200 is a cell-surface marker involved in autoimmunity. ${ }^{13,14}$ In a recent study using navigated laser capture microdissection and microarray analysis, CD200 was proposed as a specific follicular stem cell marker in humans. ${ }^{11}$ Fluorescence-activated cell sorting (FACS) analysis showed that CD200, combined with other cell-surface markers, successfully enriched a putative human follicular stem cell population.

Another cell-surface marker, CD34, is also expressed on murine follicular stem cells at the bulge. ${ }^{15}$ In humans, however, anti-CD34 antibodies failed to label the bulge, but instead labeled the proximal (lower) half of the ORS. ${ }^{16,17}$ A recent study confirmed that CD271 (p75-neurotropin

\footnotetext{
'Department of Plastic Surgery, University of Tokyo, Tokyo, Japan and ${ }^{2}$ Division of Research and Development, Biomaster Inc., Yokohama, Japan Correspondence: Professor K Yoshimura, MD, Department of Plastic Surgery, University of Tokyo School of Medicine, 7-3-1, Hongo, Bunkyo, Tokyo 113-8655, Japan. E-mail: yoshimura-pla@h.u-tokyo.ac.jp

Received 16 February 2009; revised 31 March 2009; accepted 7 April 2009
} 
receptor), known as a marker of neural stem cells or neural crest cells, ${ }^{18}$ was also expressed in the human proximal ORS; ${ }^{19}$ thus its expression pattern resembled that of CD34.

The ultimate purpose of this study was to isolate a stem cell population for clinical applications. This required a comprehensive survey of all subpopulations in the hair follicle. We first characterized human follicular stem cells and their progeny cells by examining, both in situ and in vitro, the expression patterns of stem-cell-associated biomarkers in follicular epithelial lineage cells. Further, we aimed to determine which markers were highly specific for human hair follicle stem cells and are useful in clinical settings. This study will provide knowledge for identifying biomarkers or biomarker combinations that are useful for isolating cell populations from living tissue or cultured cells that are valuable for future regenerative cell therapies.

\section{MATERIALS AND METHODS Immunohistochemistry}

Healthy human scalp skin was obtained from facelift patients with the approval of the ethical committee. Anagen hair follicles were freshly dissected and divided into single hair follicle units under a microscope. Each single hair follicle was immediately frozen in a drop of OCT compound (Sakura Finetek, Tokyo, Japan) on a piece of tin foil cooled with liquid nitrogen and stored at $-80^{\circ} \mathrm{C}$ until processing. Consecutive $5-\mu \mathrm{m}$-thick sections were sliced with a cryostat and mounted serially on separate slides for four different immunostains against K15, CD200, CD34, and CD271. We also prepared consecutive sections for staining against cytokeratin 1 (K1), cytokeratin 14 (K14), $\beta-1$ integrin (CD29), and $\alpha-6$ integrin (CD49f). In the same manner, we prepared a set of transverse serial sections. After defrosting and air drying for $10 \mathrm{~min}$, each section was fixed in $4 \%$ paraformaldehyde (PFA; Wako, Tokyo, Japan) for $30 \mathrm{~s}$ at room temperature, and incubated for $1 \mathrm{~h}$ with mouse antihuman K15 monoclonal antibody (mAb; 1:300, clone LHK15; Lab Vision, Fremont, CA, USA), CD200 mAb (1:50, clone MRC OX104; GeneTex, San Antonio, TX, USA), CD34 mAb (1:300, clone QBEnd10; Dako, Glostrup, Denmark), or CD271 mAb (1:50, clone ME20.4; Abcam Inc., Cambridge, MA, USA). The incubation was followed by visualization with the EnVision peroxidase-DAB system (Dako). An additional heat-induced antigen retrieval procedure was performed with the Target Retrieval Solution (Dako) before staining with anti-human CD34 mAb. Immunostaining against other cytokeratins and $\mathrm{CD}$ markers was performed with the following primary antibodies: anti-human $\mathrm{K} 1 \mathrm{mAb}$ (1:300, clone AE1; Progen, Heidelberg, Germany), antihuman K14 mAb (1:300, clone LL002; Abcam Inc.), anti-human CD29 mAb (1:100, clone 4B7R; Acris Antibodies, Hiddenhausen, Germany), and anti-human CD49f mAb (1:100, clone MP4F10; R\&D Systems Inc., Minneapolis, MN, USA). Nuclear counterstaining was performed with hematoxylin.

\section{Isolation and Preparation of Cell Suspensions}

The hairy scalp of the human temporal region was cut into 3-mm square pieces and incubated in DMEM supplemented with $10 \%$ fetal bovine serum (Invitrogen-Molecular Probes) and 1000 units per $\mathrm{ml}$ of Dispase I (Sanko Junyaku, Tokyo, Japan) at $4^{\circ} \mathrm{C}$ for $12-16 \mathrm{~h}$. Epithelial components, epidermis, and hair follicles were separated en bloc from a dermal component, and then were cut apart into epidermal and follicular portions with microscissors under a stereomicroscope. Epidermis- and follicle-derived epithelial cells were isolated by enzymatic digestion of each portion using $0.25 \%$ trypsin with $0.03 \%$ EDTA at $37^{\circ} \mathrm{C}$ for $30 \mathrm{~min}$. To obtain a cell suspension, the isolated cells were filtrated through a $40-\mu \mathrm{m}$-pore nylon mesh cell strainer (BD Falcon, Franklin Lakes, NJ, USA). Then cells were subjected to flow cytometry assays or cultivated through three passages in a defined keratinocyte serum-free medium (DKSFM; Invitrogen-Gibco) for FACS analysis and immunocytochemistry.

\section{Flow Cytometry Analysis for Cytokeratins and Surface Antigens}

Freshly isolated cell suspensions were analyzed for expression of cytokeratins or cell-surface markers with a FACS Aria (BD Biosciences, San Jose, CA, USA) equipped with analyzing software (FACS Diva; BD Biosciences). Contaminated dead cells were sorted out by 7-AAD (1:300; BD Pharmingen) staining; 7-AAD-negative cells (viable cells) were collected and fixed in 4\% PFA for $5 \mathrm{~min}$ at room temperature, followed by permeabilization with $0.03 \%$ saponin (Sigma-Aldrich, St Louis, MO, USA) for $5 \mathrm{~min}$ at room temperature, according to the method previously reported. ${ }^{20}$ For immunostaining intracellular cytokeratins, a purified mouse anti-human $\mathrm{K} 1 \mathrm{mAb}$ (1:300, clone AE1), K14 mAb (1:300, clone LL002), or K15 mAb (1:300, clone LHK15) was used as the primary antibody and FITC-conjugated goat anti-mouse IgG (BD Pharmingen) was used as the secondary antibody. Surface markers were detected by the following fluorescent-conjugated antibodies: PE-, APC- or PE-Cy7-conjugated mouse antihuman CD200, CD34, CD29, CD49f mAb (1:100, clones MRC OX-104, 8G12, MAR4, GoH3, respectively; BD Pharmingen), and CD271 mAb (1:100, clone ME20.4-1.H4; Miltenyi Biotec, Bergisch Gladbach, Germany).

For multicolor staining, cell suspensions were first incubated with primary antibodies against cytokeratins and secondary antibodies, washed with PBS supplemented with $0.2 \%$ bovine serum albumin, and then incubated with antibodies against surface markers. All incubations with detection antibodies were performed on ice for $30 \mathrm{~min}$. Each gating that divided antigen-positive or -negative fractions was made by comparing stained areas with negative control isotype IgGs. The percentage of cells positive for each antigen was evaluated by at least three independent experiments. 


\section{Cell Sorting of Fresh Keratinocytes and Subsequent Colony-Forming Assays}

Freshly isolated human follicle-derived epithelial cells were sorted with mouse anti-human CD200 (PE-conjugated) and CD34 (PE-Cy7-conjugated) monoclonal antibodies as described above. The sorting gates for the forward scatter (FSC) were set to divide the total cell population into two subpopulations (FSC ${ }^{\text {high }}$ and FSC ${ }^{\text {low }}$ cells) with nearly equal cell numbers. After cell sorting, 1000, 3000, or 10000 cells were seeded onto six-well culture dishes (BD Falcon) and cultured in DKSFM. To optimize cell adherence to the dish, we also seeded sorted cells onto type IV collagen- or laminincoated dishes (Biocoat; BD Falcon). Culture medium was refreshed once every 3 days. After 2 weeks of cultivation, colonies were stained as previously reported, ${ }^{21}$ with some modifications. Briefly, adherent cells were fixed in 4\% PFA in PBS for $5 \mathrm{~min}$ at room temperature, washed in PBS, and stained for $30 \mathrm{~min}$ at room temperature with 'Rhodanile blue', prepared as a mixture of $2 \%$ Rhodamine $\mathrm{B}$ (Sigma-Aldrich) and 2\% Nile blue (Sigma-Aldrich) diluted in ethanol. Then the dishes were immersed in a moderate stream of tap water for 2-3 min to wash out the excessive color and air-dried for a day. Binary format images of dishes were obtained with a scanner (Docucenter Color a360; Fuji Xerox, Tokyo, Japan). The number and size (pixels within each colony) of colonies in each well were quantified using digital imaging software (Photoshop; Adobe Systems Inc., San Jose, CA, USA).

\section{Cell-Cycle Assay}

Freshly isolated human follicle-derived epithelial cells were fixed with PFA and permeabilized with saponin as described above. Cells were incubated in PBS containing 1:20 propidium iodide (PI; Sigma-Aldrich) and 1:5 Purelink RNase A (Invitrogen) at room temperature for $30 \mathrm{~min}$. After washing cells with PBS, surface antigens were immunostained as described above. CD200 and CD34 were detected by FITCconjugated anti-human CD200 mAb (1:100, clones MRC OX-104; Affinity BioReagents, Golden, CO, USA) and PECy7-conjugated anti-human CD34 mAb (1:100; BD Pharmingen), respectively. DNA contents of cells were measured based on the fluorescence intensity of PI.

\section{Immunocytochemistry}

Both follicle- and epidermis-derived epithelial cells were cultured in DKSFM; each passage was performed at approximately $70 \%$ of cell confluency. At the third passage, cells were seeded on eight-well glass-bottom slides (Lab-Tek II Chamber Slide System; Nalge Nunc International KK, Tokyo, Japan) and 5 days after seeding, immunocytochemistry was performed for K15, CD200, CD34, CD271, K1, K14, CD29, or CD49f. The primary antibodies were the same as those used in the immunohistochemistry. Cells cultured on the slides were washed, fixed in 4\% PFA for $5 \mathrm{~min}$ at room temperature, and incubated with primary antibodies for $30 \mathrm{~min}$ at room temperature. Next, they were incubated with a secondary antibody, either Alexa Fluor 488- or Alexa Fluor 546-conjugated goat anti-mouse IgG, and were subjected to nuclear staining with Hoechst 33342. Stained slides were observed under a fluorescence microscope (BioZero).

\section{Statistical Analysis}

For evaluation of flow cytometry data, the paired Student's $t$-test was applied to compare the percentage of cell numbers or FSC values of subpopulations. The level of significance was taken as $P<0.05$.

\section{RESULTS}

Differential Expression of K15, CD200, CD34, and CD271 The ORS is the outermost epithelium in the hair follicle; it merges distal to the epidermis and proximal to the bulb. ${ }^{22}$ In this study, the ORS was divided into four portions from distal to proximal ends: the 'infundibulum', the 'bulge', the 'sub-bulge', and the 'lower ORS', as shown in Figure 1a. The infundibulum was the most distal part of the ORS; its proximal boundary was the sebaceous gland duct. In this study, we defined the bulge region with the accepted anatomical boundaries: ${ }^{7}$ its distal boundary was the sebaceous gland duct and its proximal boundary was the insertion of APM. A portion, which was proximal to the bulge and distal to the bulb, was divided at the middle into two portions; the distal half was called sub-bulge, whereas the proximal half was referred to as lower ORS in this study (Figure 1a).

Immunohistology of longitudinal serial sections of an anagen hair follicle and the epidermis demonstrated differential expression patterns of biomarkers. As reported previously, ${ }^{9,11,17,19,23}$ K15 (bulge marker), CD200 (bulge marker), CD34, and CD271 were strongly and differentially expressed in the outermost layer of the ORS in cells that adhered to the basement membrane ('basal cells'; Figure 1a). Other cytokeratins (K1 and K14) and integrins

Figure 1 Biomarker expression profiles in human epidermis and the anagen hair follicle. (a) Left: anatomy of a human anagen hair follicle (Elastica van Gieson staining). The outer root sheath (ORS) is divided into the infundibulum, bulge, sub-bulge, and lower ORS; the bulge was defined as the part between the attachment of the sebaceous gland (SB) duct (black arrow) and the insertion of the arrector pili muscle (APM) (white arrow). Scale bars $=200 \mu \mathrm{m}$. Right: representative serial sections of a human anagen hair follicle immunostained for K15, CD200, CD34, CD271, K14, K1, CD29, or CD49f shown at a low magnification. Immunoreactivity was visualized with DAB (brown color). Scale bars $=200 \mu$ m. (b) Representative sections of human epidermis immunostained for K15, CD200, CD34, and CD271. Immunoreactivity was visualized with DAB (brown color). Scale bars $=50 \mu \mathrm{m}$. K15 + cells were scattered in the basal layer and CD271 + cells were in the basal layer on the dermal papilla; CD200 or CD34 were not detected in epidermal cells. Arrowheads: positively stained basal cells. 

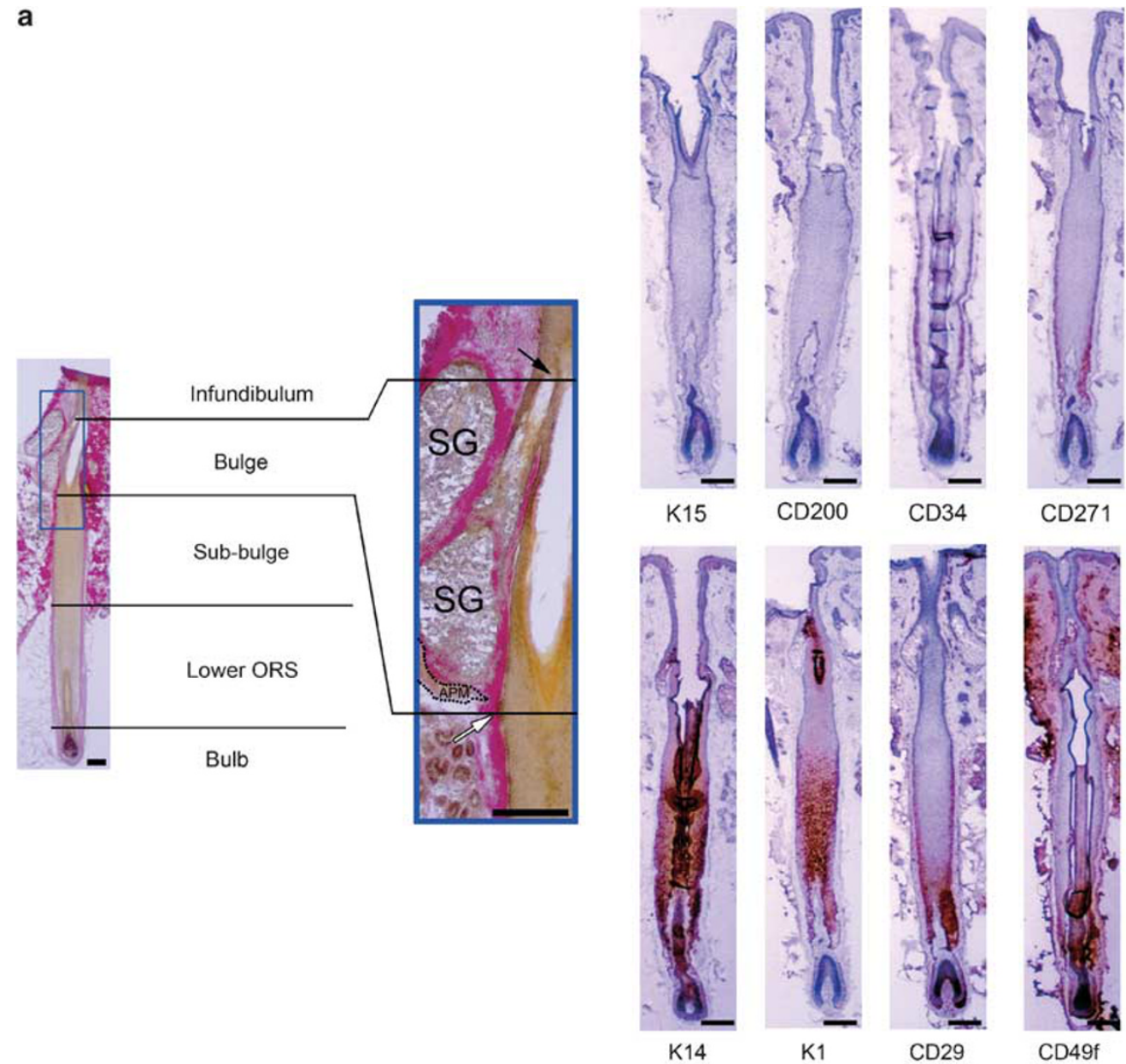

b

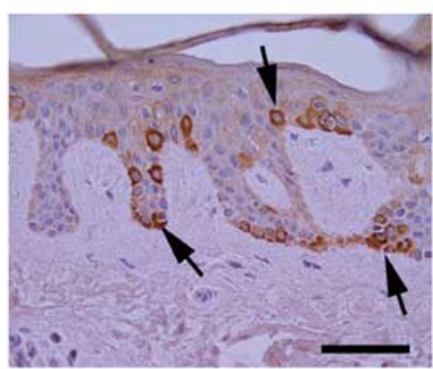

K15

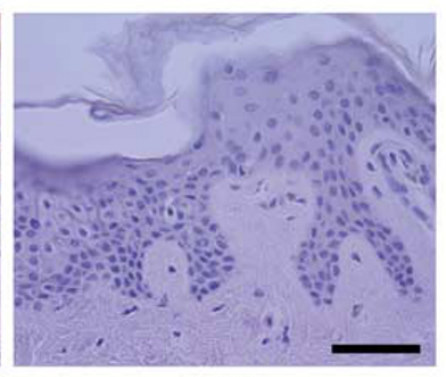

CD200

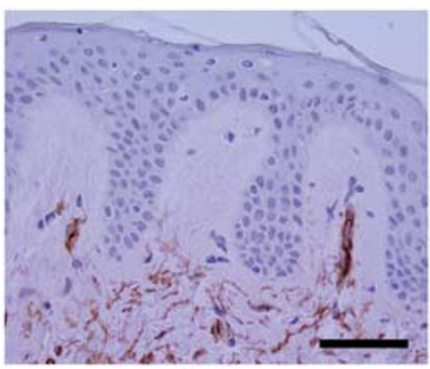

$\mathrm{CD} 34$

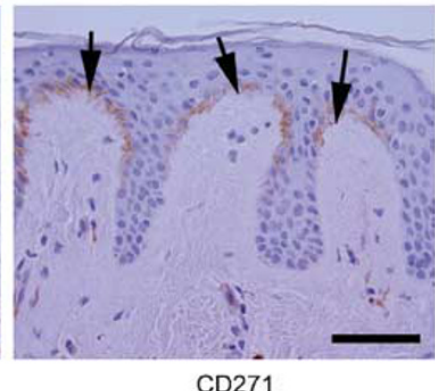


(CD29 and CD49f) were differentially and widely expressed in the epithelial component within the follicle (Figure 1a). K15 was occasionally expressed in epidermal basal keratinocytes and CD271 was expressed in basal keratinocytes located at the top of the dermal papilla (Figure 1b); however, CD200 and CD34 were not expressed in epidermal cells.

Although both K15 and CD200 were expressed in the bulge, as expected, ${ }^{9,11,23}$ our results revealed that the areas of expression for the two markers are distinct from each other. CD200 was expressed in a limited range around the bulge, whereas K15 was expressed widely in both the peri-bulge and sub-bulge areas (Figure $2 \mathrm{a}$ and $\mathrm{b}$ ). In addition, we found that $\mathrm{CD}^{200}{ }^{+}$basal ORS cells were rarely co-stained for CD34 and never co-stained for $\mathrm{CD} 271$, whereas the $\mathrm{K}^{+} 5^{+}$basal ORS cells located in the sub-bulge area always expressed CD34 (Figure 2a and $\mathrm{b}$ ).

K15 was exclusively expressed in basal ORS cells, whereas CD200, CD34, and CD271 were weakly expressed also in suprabasal ORS cells (Figure 2a and b). In the bulge, basal ORS cells were $\mathrm{K}^{+}{ }^{+} \mathrm{CD} 200^{+}$, but suprabasal counterparts were $\mathrm{K}_{15} \mathrm{CD}^{-} 00^{+}$, consistent with previous reports. ${ }^{9,11}$ In the sub-bulge region, suprabasal cells weakly expressed CD200 and also expressed CD34. In the lower ORS, most suprabasal ORS cells expressed both CD34 and CD271. The expression profiles of the biomarkers are summarized in Table 1 and Supplementary Figure 1; the differences in longitudinal distribution of expression between CD200 and K15 and between CD34 and 271 are novel findings.

\section{Biomarker Expression Assessed with Single-Color Flow Cytometry}

Freshly isolated epidermal and follicular epithelial cells were subjected to single-color FACS analysis (Figure 3a). Folliclederived keratinocytes contained a distinct population of $\mathrm{CD}^{200^{+}}$cells; a significantly larger number of cells were $\mathrm{CD}^{200}{ }^{+}$compared to isolated epidermal cells (Figure 3b). This reflected specific localization of CD200 to the peri-bulge area. In contrast, the expression of K15, CD29, and CD49f was similar in the two groups. Follicle-derived cells also contained more $\mathrm{CD} 34^{+}, \mathrm{CD} 271^{+}$, and $\mathrm{K}^{+}$cells than epidermis-derived cells. K14 was expressed at high levels and K1 at low levels in isolated epidermal epithelial cells. This suggested that basal keratinocytes were isolated and collected from the epidermal fragment more efficiently than suprabasal keratinocytes.

\section{Reduced Expression of Stem-Cell-Associated Markers with Cultivation}

Immunocytochemistry of cultured follicle- or epidermis-derived keratinocytes (passage 3) showed that the expression of CD200, K15, CD34, and CD271 was nearly undetectable in both groups; moreover, no apparent differences were observed in the expression of CD29, CD49f, K1, and K14 between cultured follicular and epidermal keratinocytes (Figure 3c). Similarly, FACS analysis showed that the expression of
CD200, K15, and CD34 was markedly reduced in follicular keratinocytes after cultivation (Figure 3d).

\section{Multicolor FACS Analyses of Freshly Isolated Cells}

Multicolor flow cytometry showed a well-demarcated $\mathrm{CD}_{200}{ }^{+}$population in freshly isolated follicular cells, but not in freshly isolated epidermal keratinocytes (Figure 4a). To focus more on bulge cells, we further analyzed $\mathrm{CD} 200{ }^{+} \mathrm{CD} 34^{-}$cells; $\mathrm{K} 15$ expression of $\mathrm{CD} 200{ }^{+} \mathrm{CD} 34^{-}$cells was half positive and half negative (Figure $4 \mathrm{a}$ ). The $\mathrm{K}^{+} 5^{+}$ and $\mathrm{K}^{-} 5^{-}$populations were distinct from each other in cell size (FSC value); the $\mathrm{CD} 200^{+} \mathrm{CD} 34^{-} \mathrm{K} 15^{+}$population corresponded predominantly to basal bulge cells and was significantly larger in cell size than the $\mathrm{CD} 200^{+} \mathrm{CD} 34^{-} \mathrm{K} 15^{-}$ population, which was considered to be suprabasal bulge cells (Figure 4b).

Freshly isolated follicle-derived cells were further analyzed with multicolor FACS for detailed cell compositions (Figure 4c). A summary of cell composition is shown in Table 2. A major portion of $\mathrm{CD} 34^{+}$cells were $\mathrm{K}^{+} 5^{+}$. In addition, the $\mathrm{CD} 200^{+} \mathrm{CD} 34^{-} \mathrm{K} 5^{+}$subpopulation showed a higher expression rate of $\mathrm{CD} 29$ than the $\mathrm{CD} 200^{+} \mathrm{CD} 34^{-} \mathrm{K} 15^{-}$subpopulation (Figure 4c), whereas both populations showed similar expression rates of CD49f and almost no expression of CD271 (Figure $4 \mathrm{c}$ and d).

\section{Colony-Forming Assays of Freshly Isolated Follicular Epithelial Subpopulations}

Because immunostaining for K15 required cell fixation and permeabilization of the cell membrane, sorted $\mathrm{K}^{+} 5^{+}$cells could not be cultured. Therefore, we isolated K15-rich or K15-poor subpopulations from a viable $\mathrm{CD} 200^{+}$fraction by gating for FSC (cell size) because the $\mathrm{CD} 200^{+} \mathrm{CD} 34^{-} \mathrm{K} 15^{+}$ population had a larger average size than the $\mathrm{CD} 200^{+} \mathrm{CD} 34^{-} \mathrm{K} 15^{-}$population, as described above (Figure $4 \mathrm{~b})$. Thus, we sorted four subpopulations of freshly isolated follicular epithelial cells: (1) $\mathrm{CD} 200^{+} \mathrm{CD} 34^{-} \mathrm{FSC}^{\text {high }}$ cells (K15-rich), (2) $\mathrm{CD}^{200}{ }^{+} \mathrm{CD} 34^{-} \mathrm{FSC}^{\text {low }}$ cells (K15-poor), (3) CD $34^{+}$FSC $^{\text {high }}$ cells, and (4) CD $34^{+}$FSC $^{\text {low }}$ cells (Figure 5a). We confirmed that the $\mathrm{CD} 200^{+} \mathrm{CD} 34^{-} \mathrm{FSC}^{\text {high }}$ population contained a significantly higher percentage of $\mathrm{K}^{+} 5^{+}$cells than the $\mathrm{CD} 200^{+} \mathrm{CD}^{-} 4^{-} \mathrm{FSC}^{\text {low }}$ population (Figure 5a).

In all types of culture dishes (noncoated, type IV collagencoated, and laminin-coated), both $\mathrm{CD} 200^{+} \mathrm{CD} 34^{-} \mathrm{FSC}^{\text {high }}$ (K15-rich) and $\mathrm{CD}_{200}{ }^{+} \mathrm{CD} 34^{-} \mathrm{FSC}^{\text {low }}$ (K15-poor) subpopulations yielded countable colonies at the initial concentration of 1000 cells per well (Figure 5b); thus they exhibited an extremely high efficiency compared to unsorted freshly isolated epithelial cells (data not shown). Although there were no significant differences in cell morphology among cells cultured in the three types of dishes, cell density was higher and the boundary was clearest in colonies cultured in laminin-coated dishes (data not shown). Thus, laminin-coated dished were selected for further investigations. 
a
K15

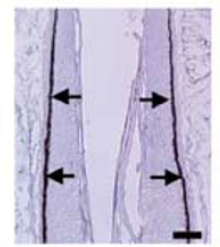

Bulge
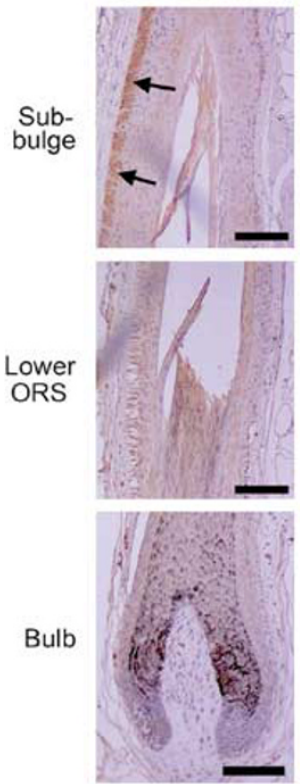

b

Bulge
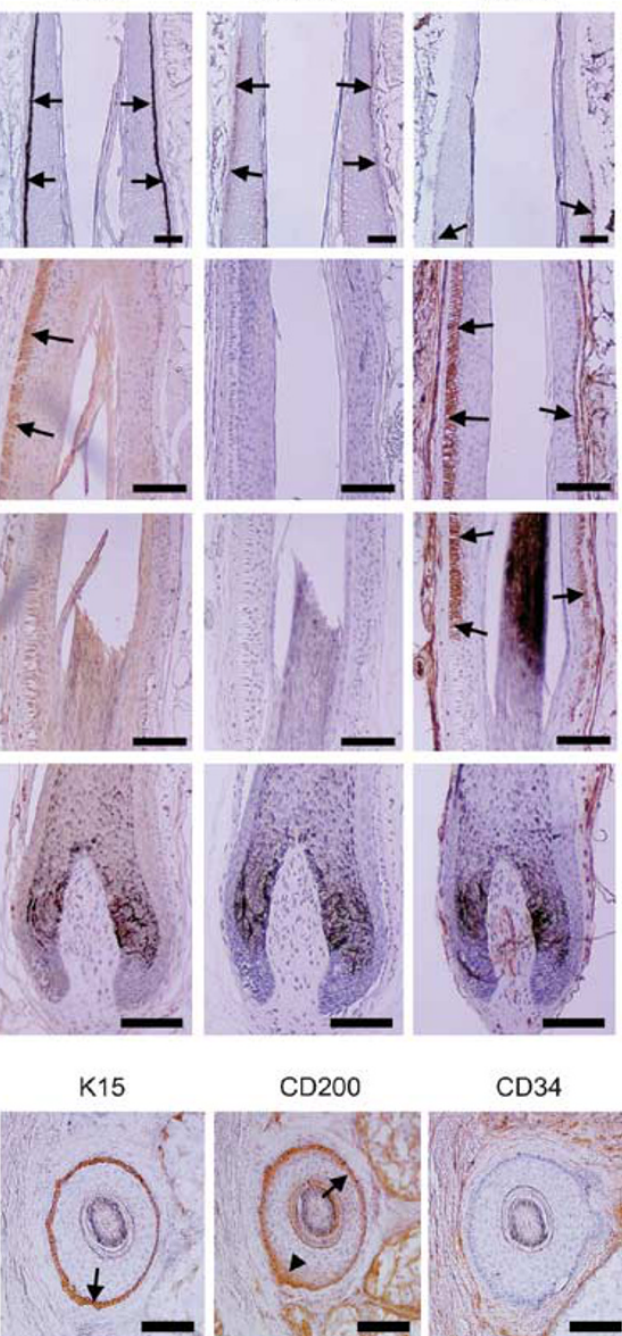

CD200

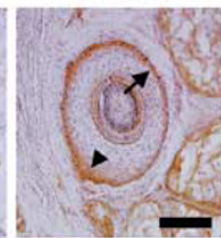

$\mathrm{CD} 34$
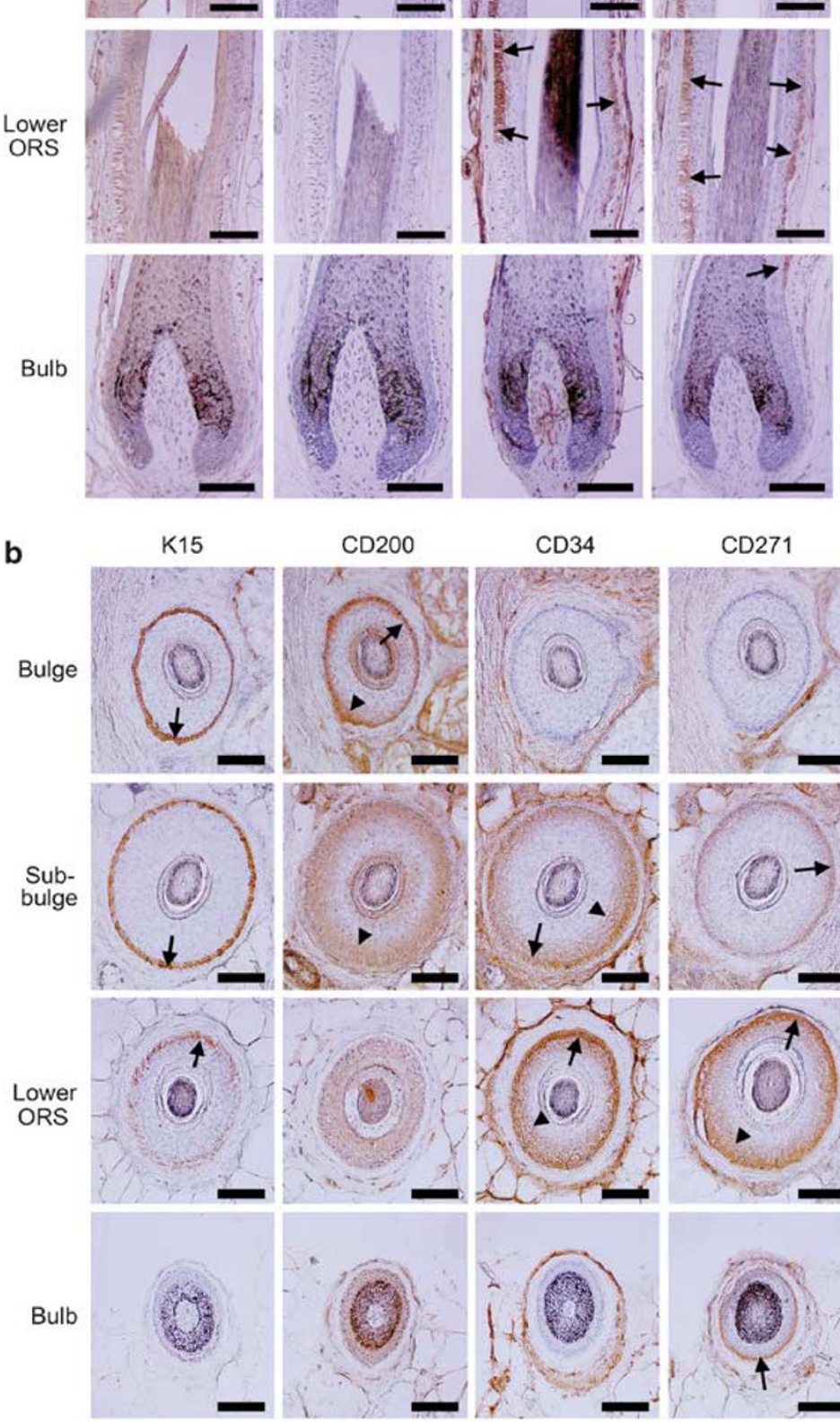

Figure 2 Biomarker expression profiles in histological sections of human anagen hair follicles. Representative serial longitudinal (a) and transverse (b) sections of human anagen hair follicles immunostained for K15, CD200, CD34, or CD271 at high magnifications. The biomarkers were differentially expressed in the outer root sheath. Arrows indicate positively stained basal ORS cells, and arrowheads indicate positively stained suprabasal ORS cells.

Immunoreactivity was visualized with DAB (brown color). Scale bars $=50 \mu \mathrm{m}$. 
Table 1 Summary of immunohistochemical staining patterns in the epithelial components of human scalp and the anagen hair follicle

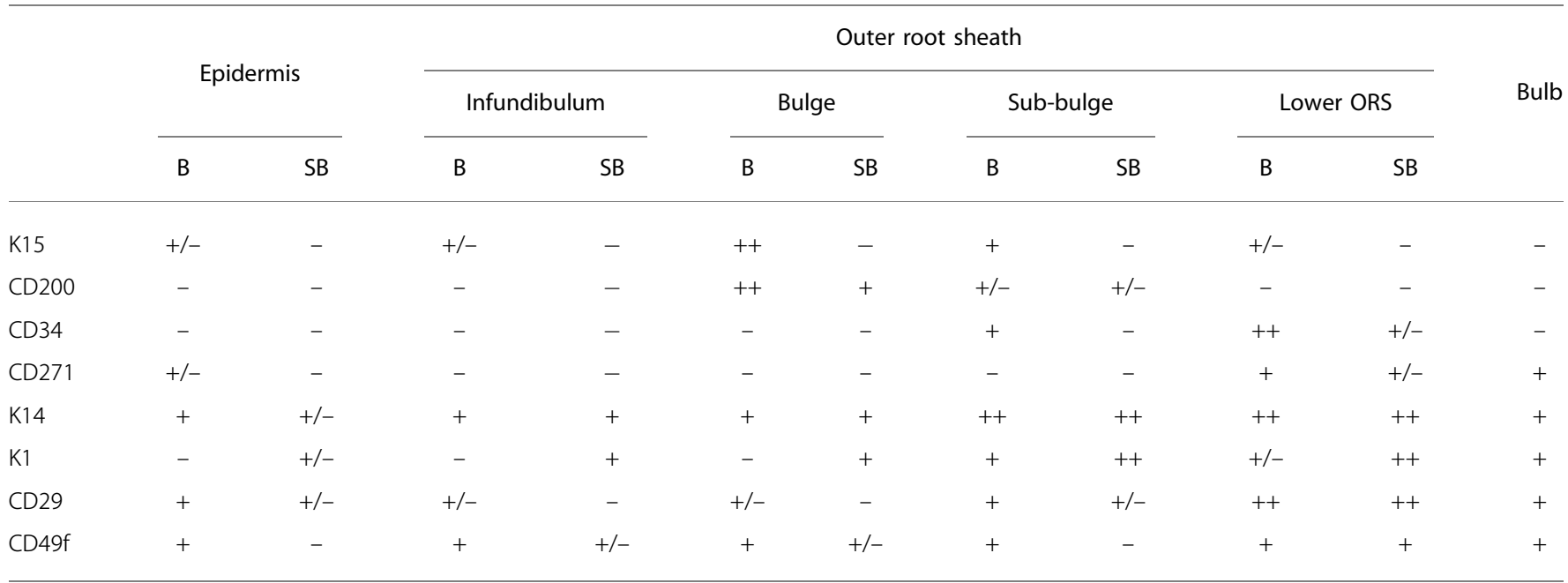

B, basal cells; SB, suprabasal cells.

A representative staining pattern is shown in terms of the immunohistochemical intensities against each antigen. Staining intensities were: - , no staining; $+/-$, marginally or partially positive staining; + , positive staining; and ' ++ , strong positive staining.

At any seeding density, the $\mathrm{CD} 200^{+} \mathrm{CD} 34^{-}$cell fraction showed a much higher colony-forming ability than the $\mathrm{CD} 4^{+}$cell fraction; moreover, there were striking differences in the numbers and sizes of colonies in CD200 $\mathrm{CD} 34^{-}$cells and $\mathrm{CD} 34^{+}$cells (Figure $5 \mathrm{~b}$ and c). In addition, there were significant differences in numbers and sizes of colonies between $\mathrm{CD} 200^{+} \mathrm{CD} 34^{-} \mathrm{FSC}^{\text {high }}$ (K15-rich) and $\mathrm{CD} 200^{+} \mathrm{CD}^{-} 4^{-} \mathrm{FSC}^{\text {low }}$ (K15-poor) populations (Figure $5 \mathrm{c}$ ). The $\mathrm{CD} 200^{+} \mathrm{CD}^{-} 4^{-} \mathrm{FSC}^{\text {high }}$ (K15-rich) population gave rise to a smaller number of colonies with larger sizes, whereas the $\mathrm{CD} 200^{+} \mathrm{CD} 34^{-} \mathrm{FSC}^{\text {low }}$ (K15-poor) population formed a larger number of colonies with smaller sizes (Figure $5 \mathrm{c}$; Supplementary Figure 2).

\section{Cell-Cycle Analysis of Freshly Isolated Follicular Epithelial Subpopulations}

Cell-cycle analysis showed that most of both $\mathrm{CD} 200^{+} \mathrm{CD} 34^{-} \mathrm{FSC}^{\text {low }}(\mathrm{K} 15$-poor $)$ and $\mathrm{CD} 200^{+} \mathrm{CD} 34^{-}$ FSC $^{\text {high }}$ (K15-rich) cells were in $\mathrm{G}_{0} / \mathrm{G}_{1}$ phase (Figure 6a), indicating they were rarely dividing and in quiescent status. There was no significant difference in the distribution of each phase between the two populations. In contrast, $\mathrm{CD} 34^{+}$cells contained substantial number of $S-$ and $\mathrm{G}_{2} / \mathrm{M}$ phase cells compared to $\mathrm{CD} 200^{+} \mathrm{CD} 34^{-}$cells (Figure $6 \mathrm{~b}$ ), indicating more contamination of rapidly dividing cells within the $\mathrm{CD} 4^{+}$population.

\section{DISCUSSION}

Our immunohistochemical assessment of scalp and follicle sections revealed that stem-cell-associated biomarkers were differentially expressed in the epidermis and anagen hair follicles. In the epidermis, K15 and CD271 were expressed in some of the basal keratinocytes; $\mathrm{K} 15^{+}$keratinocytes appeared to be randomly distributed in the basal layer, whereas $\mathrm{CD} 271^{+}$keratinocytes were strictly located on the top of each dermal papilla. This specific localization of CD271 ${ }^{+}$ keratinocytes appears to correlate with their biological function, though this has not been clarified.

Given that follicular keratinocytes migrate down along the basement membrane from the bulge to the bulb, our data also suggested that follicular keratinocytes differentially express stem-cell-associated biomarkers according to their differentiation stages; they initially express K15 and CD200 in the bulge, and gradually alter their expression to CD34 and subsequently to CD271 as they migrate down to the bulb (Supplementary Figure 1). Thus, unlike rodent CD34, human CD34 could not be regarded as a bulge marker in this study, consistent with previous reports. ${ }^{17,23}$ Recent reports suggested that CD34 and CD271 were expressed in human hair follicles, especially in the ORS proximal to the attachment site of the APM. ${ }^{16,17,19}$ Our immunohistological assays demonstrated a similar staining pattern; however, we report for the first time that CD271 was expressed proximal to CD34. CD29 and CD49f, which are expressed around the bulge in rodents, were widely expressed in human hair follicles, and could not be used as a specific marker for the bulge in humans.

K15 and CD200 were expressed in the bulge, though they did not have the same expression pattern. K15 was expressed only in the basal layer of the bulge, and over an unexpectedly wide longitudinal range from the infundibulum to the lower ORS. $\mathrm{K} 5^{+}$and $\mathrm{CD} 34^{+}$cells appeared to partly overlap, indicating that $\mathrm{K} 15$ was also expressed in partly differentiated 

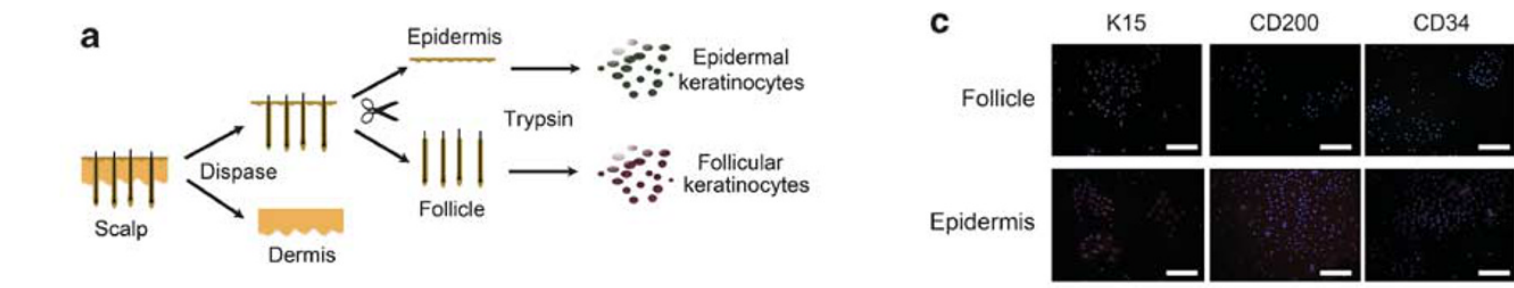

$\mathrm{CD} 271$

b
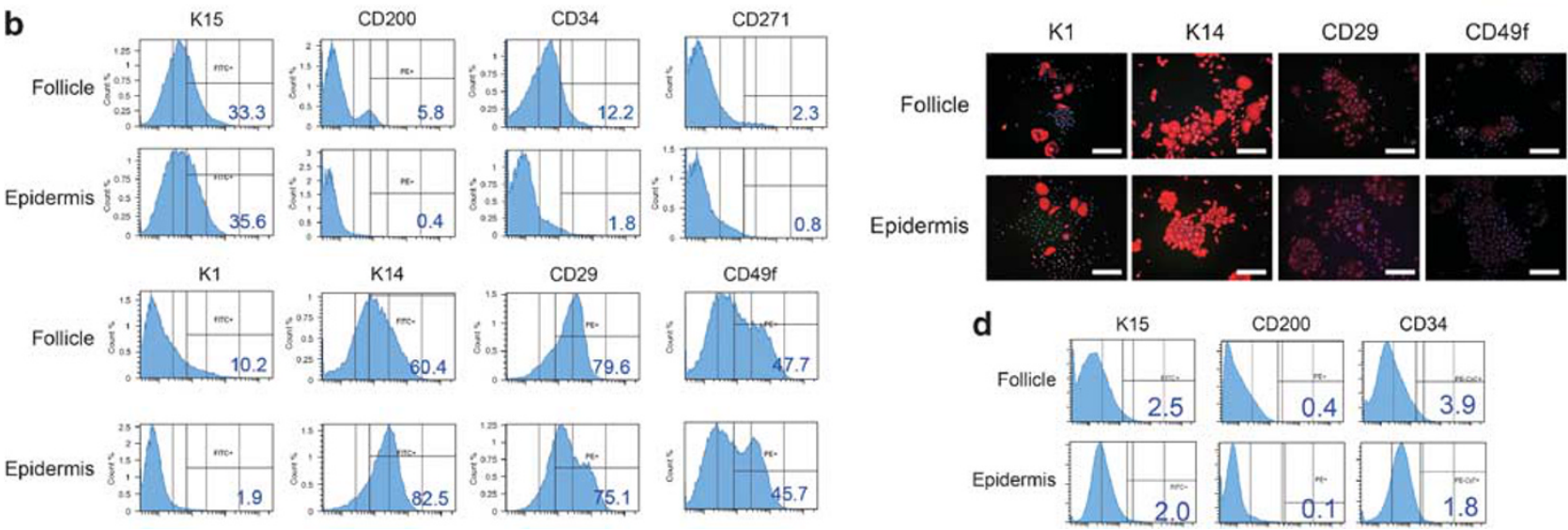

Figure 3 Biomarker expression in freshly isolated or cultured epidermal and follicular epithelial cells. (a) Schematic of the isolation and preparation of follicle- and epidermis-derived epithelial cells from the human scalp. (b) Representative data from a single-color FACS analysis of freshly isolated follicle- or epidermis-derived epithelial cells. Isolated cell suspensions were stained for K15, CD200, CD34, CD271, K14, K1, CD29, or CD49f. Note that a distinct expression pattern of CD200 was detected in follicle-derived cells compared to epidermis-derived cells. (c) Immunocytochemistry of cultured follicle- and epidermis-derived epithelial cells (passage 3) with stem-cell-associated surface markers and cytokeratins. Immunoreactivity was visualized with Alexa 546 in red; nuclei were counterstained with Hoechst 33342 in blue. Scale bars $=20 \mu \mathrm{m}$. (d) Representative data from a single-color FACS analysis of cultured follicle- or epidermis-derived epithelial cells (passage 3). Isolated cell suspensions were stained for K15, CD200, or CD34. Numbers in blue indicate percentage of positive cells. Expression of these stem-cell-associated markers substantially declined with time in culture.

keratinocytes. In contrast, $\mathrm{CD} 200^{+}$cells were rarely co-expressed with $\mathrm{CD} 34$ in the basal layer, indicating that CD200 was more specific than K15 for the basal cells in the bulge.

Multicolor flow cytometry revealed that there were various cell populations with distinct expression profiles of surface antigens in human hair follicles. Based on our results of cell composition (Table 2), we speculate that basal cell populations are more efficiently collected than suprabasal cells by our cell isolation process with collagenase digestion. The flowcytometric data appeared to reflect the histological findings; for example, CD200 ${ }^{+}$cells were CD271 ${ }^{-}$. Interestingly, we found that $\mathrm{CD} 200^{+}$cells were well fractionated and K15 expression was significantly higher in CD200 ${ }^{+}$cells of larger cell size than $\mathrm{CD}_{200}{ }^{+}$cells of smaller cell size; nevertheless, nearly $30 \%$ of the $\mathrm{CD} 200^{+} \mathrm{CD}^{-} 4^{-} \mathrm{FSC}^{\text {low }}$ cells were $\mathrm{K}_{15}{ }^{+}$.

Contrary to the staining patterns of the basal ORS cells, suprabasal ORS cells in the bulge region expressed CD200 but not K15. On the basis of conventional concepts of a stem cell niche, once epithelial stem cells have detached from the niche (the basal membrane of the bulge), an irreversible differentiation program starts. It was shown that the detachment was due to a reduction of adhesiveness to the basement membrane mediated by Myc activation. ${ }^{24}$ A recent analysis of the mouse bulge microenvironment demonstrated that the bulge region unexpectedly contained two spatially distinct multipotent stem cell subsets, one in the basal and the other in the suprabasal layer. ${ }^{25}$ In addition, a study of the bulge in the human fetus reported that interior (suprabasal) cells and outermost (basal) bulge cells showed similarly undifferentiated morphological features. ${ }^{7}$ In light of these observations, it may not be surprising that CD $200^{+}$suprabasal cells would include stem cell-like cells. Thus, we further investigated which of the two populations in the bulge, $\mathrm{K}_{15}{ }^{+} \mathrm{CD} 200^{+}$basal cells or $\mathrm{K} 15^{-} \mathrm{CD} 200^{+}$suprabasal cells, exhibited more similarity to stem cells.

Previous reports showed that murine $\mathrm{K}^{+} 5^{+}$keratinocytes are slow cycling (label-retaining cells) and possess a greater colony-forming ability; thus indicating that they are putative follicular stem cells. ${ }^{12,26}$ In humans, however, the biological properties of $\mathrm{K}^{+}$cells have not been fully examined because viable human $\mathrm{K}^{+} 5^{+}$cells cannot be purified by cell sorting due to the membrane permeabilization required for staining intracellular cytokeratins. On the other hand, $\mathrm{CD}_{200}{ }^{+}$cells can be purified; thus we sorted $\mathrm{CD} 200^{+} \mathrm{CD}^{-} 4^{-}$and $\mathrm{CD} 4^{+}$populations from isolated follicular epithelial cells. Because we found that $\mathrm{K}_{15}{ }^{+} \mathrm{CD} 200^{+}$ 
a

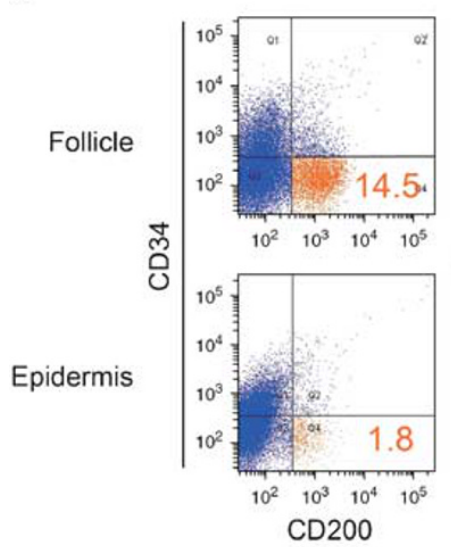

b
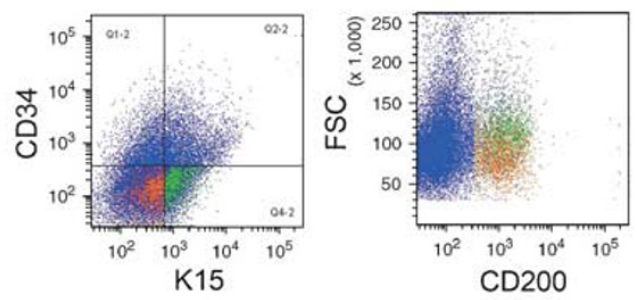

$\mathrm{CD} 200^{\circ} \mathrm{CD} 34^{-} \mathrm{K} 15^{+}$

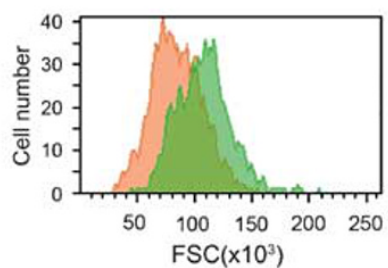

$\mathrm{CD} 200^{+} \mathrm{CD} 34^{-} \mathrm{K} 15^{\circ}$
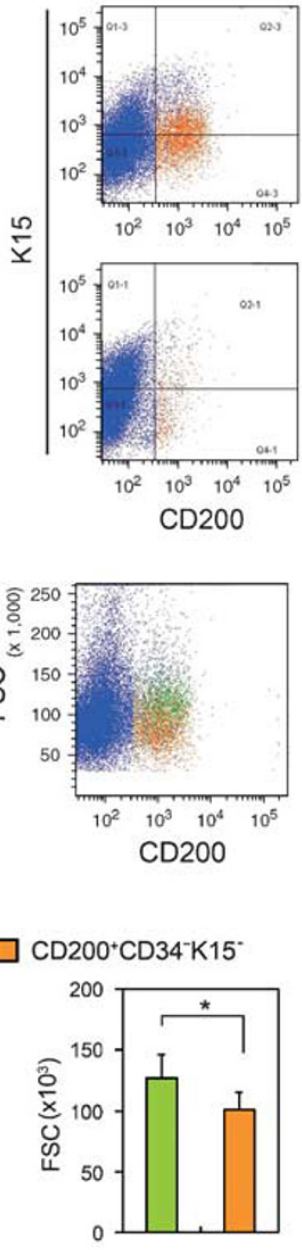

C
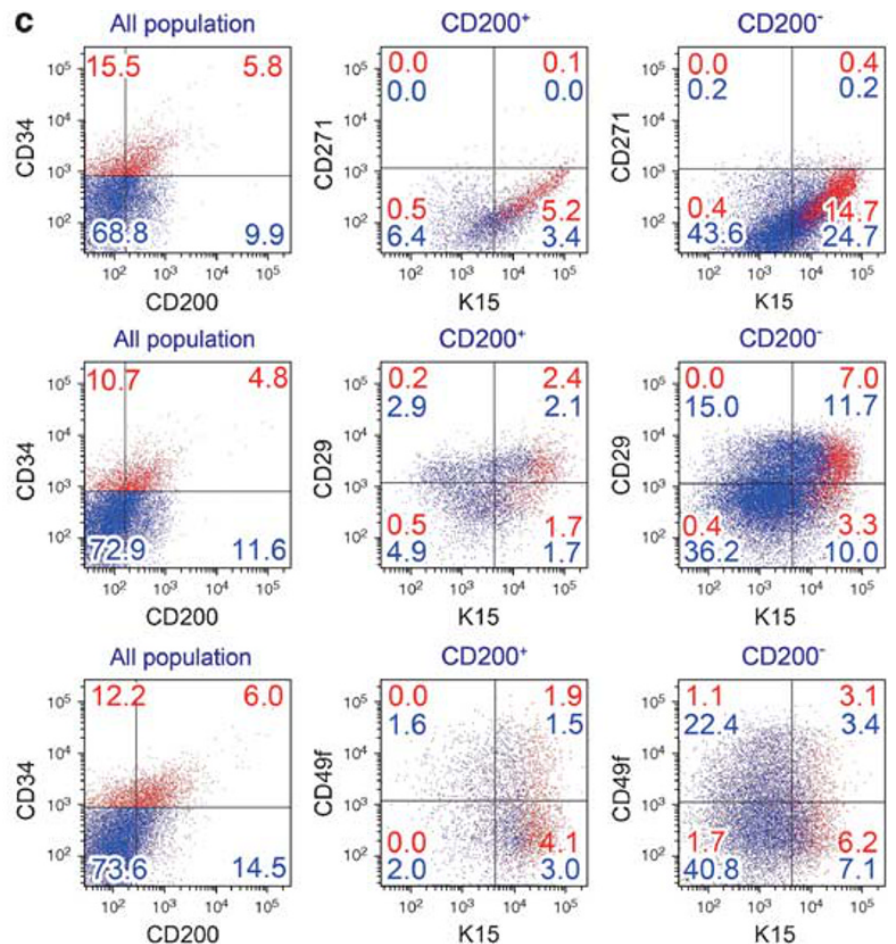

\section{d $\square \mathrm{CD} 200^{\circ} \mathrm{CD} 34^{*} \mathrm{~K} 15^{+} \square \mathrm{CD} 200^{\circ} \mathrm{CD} 34^{\circ} \mathrm{K} 15^{\circ}$}

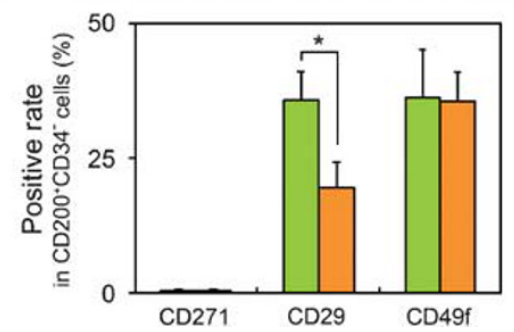

Figure 4 Multicolor FACS analyses of freshly isolated follicle- or epidermis-derived epithelial cells. (a) Representative data from a multicolor FACS assay (stained for K15, CD200, and CD34) of freshly isolated human follicle- or epidermis-derived keratinocytes. Orange-colored subpopulation indicates $\mathrm{CD} 200^{+} \mathrm{CD}_{4} 4^{-}$cells; each number indicates the percentage in the parent population. About half of the $\mathrm{CD}^{200}{ }^{+} \mathrm{CD}^{-} 4^{-}$population of follicle-derived keratinocytes was $\mathrm{K}_{15}{ }^{+}$, whereas few cells were $\mathrm{CD} 200^{+}$in the epidermis-derived population. (b) Comparative multicolor FACS analysis of freshly isolated follicle-derived epithelial cells. Cells were stained for K15, CD200, and CD34. CD200 ${ }^{+} \mathrm{CD} 34^{-}$cells were divided into $\mathrm{K} 15^{+}$and $\mathrm{K} 15^{-}$subsets (green and orange populations, respectively); a histogram demonstrates distribution of forward scatter (FSC) values in each subpopulation. The $\mathrm{CD} 200^{+} \mathrm{CD} 34^{-} \mathrm{K} 15^{+}$ population had a significantly larger average cell size than the $\mathrm{CD} 200^{+} \mathrm{CD} 34^{-} \mathrm{K} 15^{-}$population. ${ }^{\star} P<0.05$. (c) Representative data from multicolor FACS analyses of freshly isolated follicle-derived epithelial cells. Cells were stained for K15, CD200, CD34, and one of following antigens, CD271, CD29, or CD49f. The middle or right graphs show only $\mathrm{CD}_{200}{ }^{+}$or $\mathrm{CD} 200^{-}$cells; the parent population is shown in the left graphs. In all graphs, CD34 ${ }^{+}$cells were plotted in red, whereas $\mathrm{CD}_{3} 4^{-}$cells are in blue. Each red or blue number indicates the cell number percentage of the parent population. (d) Expression of CD271, $\mathrm{CD} 29$, and $\mathrm{CD} 49 \mathrm{f}$ in $\mathrm{CD} 200^{+} \mathrm{CD} 34^{-} \mathrm{K}_{15}{ }^{+}$and $\mathrm{CD} 200^{+} \mathrm{CD} 34^{-} \mathrm{K} 15^{-}$populations in freshly isolated follicle-derived epithelial cells. CD271 expression was not detected in $\mathrm{CD}_{200}{ }^{+} \mathrm{CD}_{4}^{-}$cells, whereas CD29 and CD49f were expressed in a substantial part of each population.

cells were larger (FSC ${ }^{\text {high }}$ ) in size than $\mathrm{K}^{-} 5^{-} \mathrm{CD} 200^{+}$cells, we considered it theoretically possible to separate basal bulge

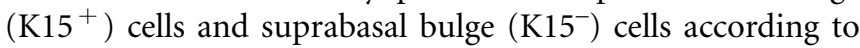
the FSC values. Thus, the $\mathrm{CD} 200^{+} \mathrm{CD} 34^{-}$cells were sorted into two populations by cell size: the K15-rich population had a larger average cell size than the K15-poor population. The two populations, CD200 ${ }^{+} \mathrm{CD} 34^{-} \mathrm{FSC}^{\text {high }}$ (K15-rich, basal) and $\mathrm{CD} 200^{+} \mathrm{CD} 34^{-} \mathrm{FSC}^{\text {low }}$ (K15-poor, suprabasal) populations, showed similar distribution in cell-cycle phases, which indicated both populations were in a quiescent status $\left(G_{0} / G_{1}\right)$. It is interesting, however, that they show striking difference in cell-dividing activity when they are observed in culture condition; subsequent colony-forming assays revealed that the $\mathrm{CD} 200^{+} \mathrm{CD}^{-} 4^{-} \mathrm{FSC}^{\text {high }}$ (K15-rich, basal) population yielded fewer colonies but with larger areas than the $\mathrm{CD} 200^{+} \mathrm{CD}^{-} 4^{-} \mathrm{FSC}^{\text {low }}$ (K15-poor, suprabasal) population. This suggested that the $\mathrm{CD}^{2} 00^{+} \mathrm{CD} 34^{-} \mathrm{FSC}^{\text {low }}$ (K15-poor, suprabasal) population contained more colony-forming cells, 
Table 2 Summary of cell compositions obtained from multi-color FACS analyses of freshly isolated follicle- or epidermis-derived epithelial cells

\begin{tabular}{|c|c|c|c|c|c|c|c|}
\hline \multirow[t]{2}{*}{ Population } & \multicolumn{4}{|c|}{ Antigen } & \multirow{2}{*}{$\begin{array}{l}\text { Composition } \\
\text { (Mean, \%) }\end{array}$} & \multirow[t]{2}{*}{ Estimated location } & \multirow[t]{2}{*}{ Symbols* } \\
\hline & $\mathrm{K} 15$ & CD200 & CD34 & CD271 & & & \\
\hline 2 & + & + & - & - & 2.4 & Bulge (basal) & B1 \\
\hline 3 & - & + & - & - & 4.9 & Bulge (suprabasal) & S1 \\
\hline 5 & - & + & + & - & 0.3 & Upper sub-bulge (suprabasal) & $\mathrm{S} 2$ \\
\hline 6 & + & - & + & - & 16.9 & Sub-bulge (basal) & B3 \\
\hline 7 & - & - & + & - & 1.1 & Sub-bulge (suprabasal) & $\mathrm{S} 2$ \\
\hline 8 & $+/-$ & - & $+/-$ & + & 1.6 & Lower ORS, bulb (basal, suprabasal) & $B 4, B 5, S 3, B$ \\
\hline
\end{tabular}

All isolated epithelial cells were categorized into nine subpopulations according to expression patterns for K15, CD200, CD34, and CD271. Data are averages of three experiments. Taken together with the immunohistological analyses of tissue sections, the results indicated the locations of each subpopulation, as listed on the right.

*Symbols are indicated in Supplementary Figure 1.

but each colony-forming cell had a limited ability to proliferate compared to cells in the $\mathrm{CD}_{20}{ }^{+} \mathrm{CD} 34^{-} \mathrm{FSC}^{\text {high }}$ (K15-rich, basal) population. On the basis of colony size, the K15-poor subset may be more differentiated than the K15rich subset showing higher efficiency of forming large colonies, though long-term cultures were not possible due to the limited number of cells; thus, we were not able to evaluate their ultimate doubling capacity. On the other hand, the $\mathrm{CD}_{2} 00^{+}$population showed much higher proliferation and was likely to be more stem cell-like than the $\mathrm{CD} 34^{+}$cells; the $\mathrm{CD} 34^{+}$cells were considered mainly basal cells in the sub-bulge and lower ORS regions, and a majority was $\mathrm{K}^{+} 5^{+}$.

It was previously reported that when human keratinocytes are isolated from the epidermis and subcultured, smaller cells such as $10-12 \mu \mathrm{m}$ gave rise to colonies more efficiently than larger cells such as $20 \mu \mathrm{m}$; the colony-forming efficiency (the rate of colony-forming cells per seeding cells) was almost in inverse proportion to the diameter of cells. ${ }^{27}$ However, the size of formed colonies was similar between small and large founded cells as far as the diameter was less than $20 \mu \mathrm{m} .^{27}$ Their results are consistent with ours showing that $\mathrm{CD} 200^{+} \mathrm{CD} 34^{-} \mathrm{FSC}^{\text {low }}$ cells (smaller suprabasal bulge cells) formed a larger number of colonies, though $\mathrm{CD} 200^{+}$ CD $34^{-}$FSC $^{\text {high }}$ cells (larger basal bulge cells) contained higher percentage of large colonies. Taken together with our results of immunohistolgy and flowcytomtery, basal bulge cells are more frequently $\mathrm{K}^{+} 5^{+}$and larger in size than suprabasal bulge cells, the latter of which were supported by a morphological study of human fetal hair follicles. ${ }^{7}$ A previous report successfully defined $\mathrm{CD} 200^{+} \mathrm{CD} 24^{\text {low }} \mathrm{CD} 34^{\text {low }}$ $\mathrm{CD} 71^{\text {low }} \mathrm{CD} 146^{\text {low }}$ cells as a potent bulge cell population with high proliferative capacity. ${ }^{11}$ However, that method required as many as five different antibodies for cell isolation. On the other hand, our method required only two biomarkers (CD200 and CD34) combined with the FSC value. This provides a simpler, more practical alternative for clinical applications.

Cultivation of epidermal or follicular keratinocytes resulted in dramatically reduced expression of K15, CD200, CD34 and CD271; however, the expression of other basal cell markers (CD29, CD49f, and K14) was sustained. This phenotypic change in cultured cells may reflect a lack of multipotency and clonogenecity. To the best of our knowledge, there have been no studies that examined whether cultured epidermal or follicular epithelial cells derived from adult humans can sustain multipotency. Further investigations are needed to clarify these matters.

In conclusion, we conducted a comprehensive survey of epithelial cell compositions of human hair follicles and found that the distribution of $\mathrm{CD} 200^{+}$and $\mathrm{K} 15^{+}$cells was spatially distinct in the human bulge. Our results with multicolor FACS analyses of freshly isolated human follicular keratinocytes and immunohistology revealed cellular composition and localization of each subpopulation in the human hair follicles. The $\mathrm{CD} 200^{+} \mathrm{CD} 34^{-} \mathrm{FSC}^{\text {high }}$ (K15-rich, basal) and the $\mathrm{CD} 200^{+} \mathrm{CD} 34^{-} \mathrm{FSC}^{\text {low }}$ (K15-poor, suprabasal) populations possessed different colony-forming abilities in vitro, although both lost their expression patterns after cultivation. Our results suggest that CD200, K15, CD34, and CD271 
a
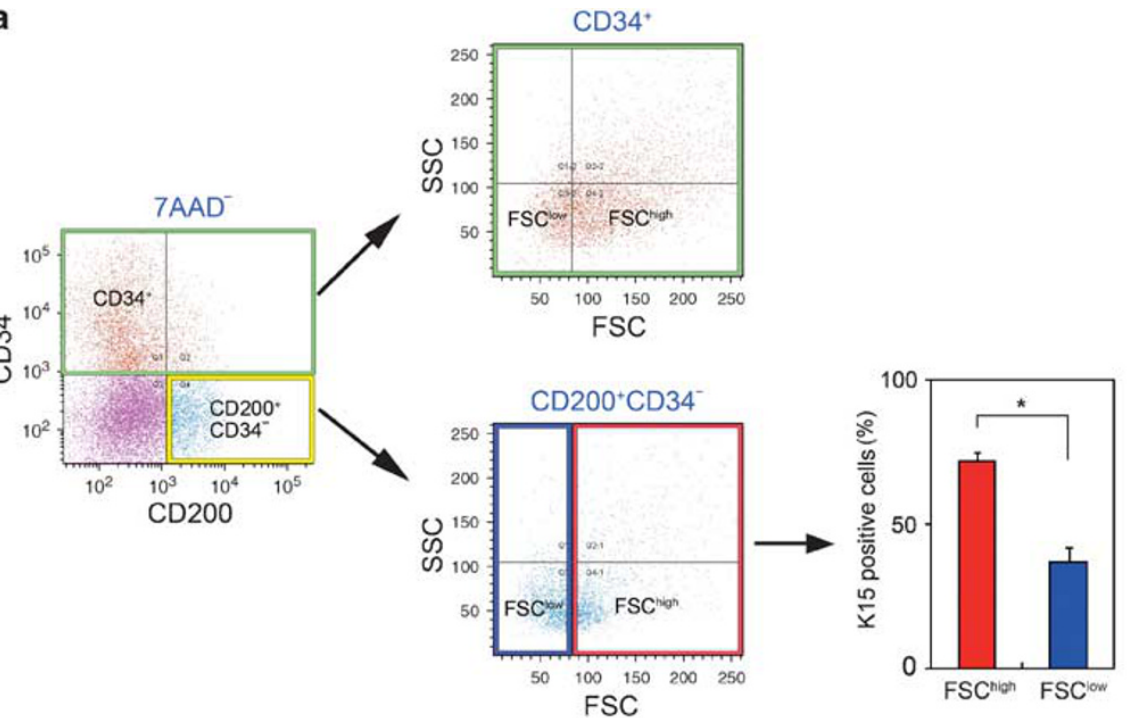

b $\frac{\text { Non-coat }}{\text { FSC }^{\text {high }} \text { FSC }^{\text {low }}} \frac{\text { Col-4 }}{\text { FSC }^{\text {high }} \text { FSC }^{\text {low }}} \frac{\text { Lam }}{\text { FSC }^{\text {high }} \text { FSC low }^{\text {low }}}$

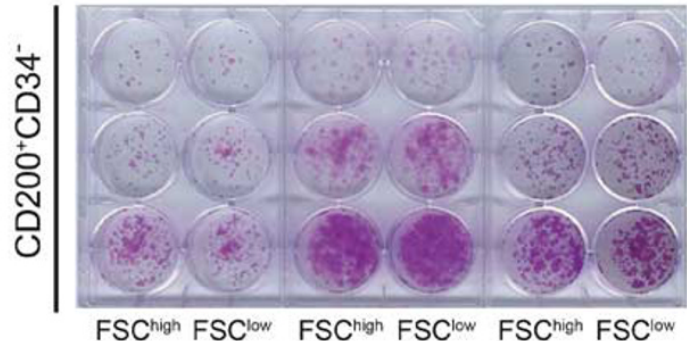

$10^{3}$

$3 \times 10^{3}$

$10^{4}$
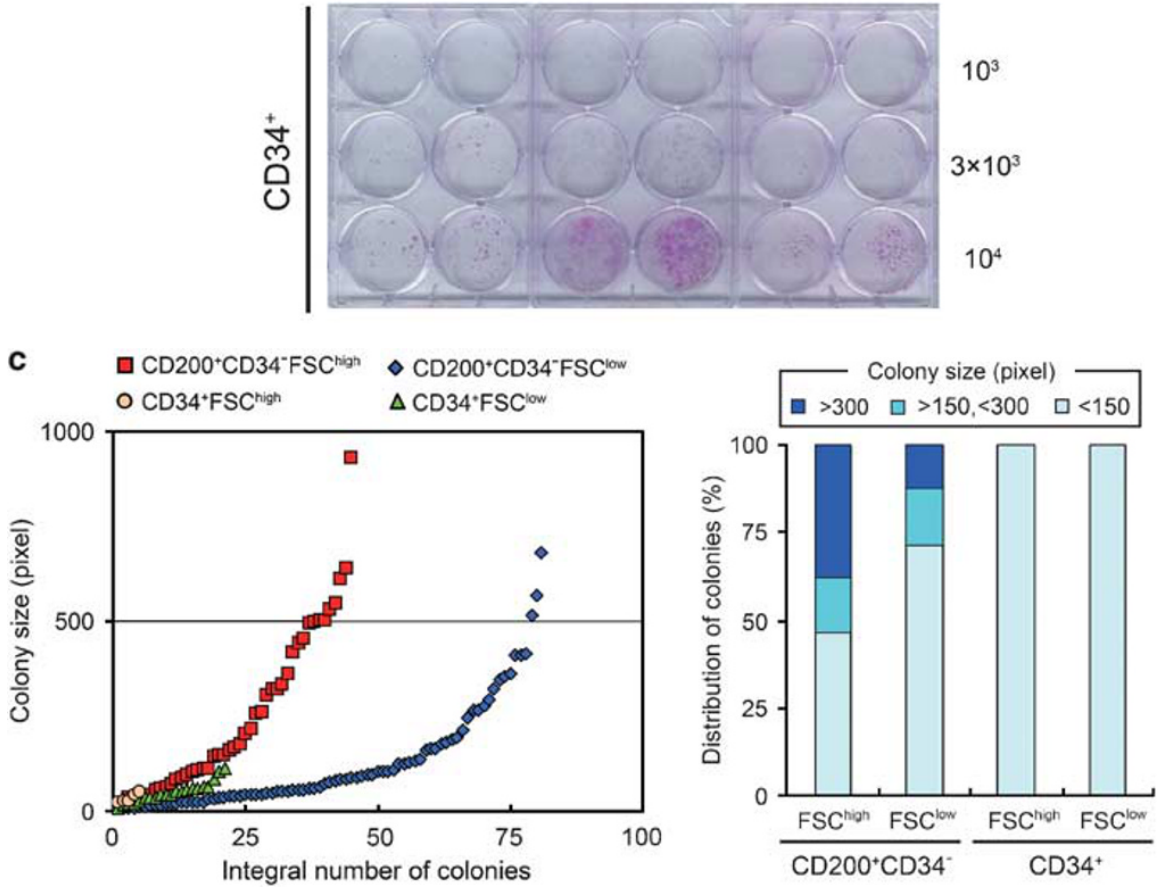
Figure 5 Comparative experiments with sorted subpopulations of freshly isolated follicle-derived epithelial cells. (a) After gating out dead 7-AAD-positive cells, cells were sorted by expression of CD200, CD34, and forward scatter (FSC; cell size). Freshly isolated follicle-derived epithelial cells were sorted and

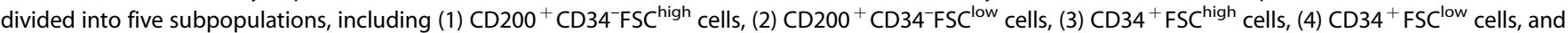
(5) others. There was a significantly higher percentage of $\mathrm{K} 15^{+}$cells in the $\mathrm{CD} 200^{+} \mathrm{CD}_{3} 4^{-} \mathrm{FSC} \mathrm{C}^{\text {high }}$ population (red) than in the $\mathrm{CD} 200^{+} \mathrm{CD} 34^{-} \mathrm{FSC} \mathrm{low}^{\mathrm{low}}$ population (blue). (b) Colony-forming assay of the four subpopulations sorted with CD200, CD34, and FSC. Cells were seeded on noncoated (non-coat), type IV collagen-coated (Col-4), or laminin-coated (Lam) dishes at an initial seeding of $10^{3}, 3 \times 10^{3}$, or $10^{4}$ cells. In all cell populations, a larger number of colonies were formed on laminin-coated or type IV collagen-coated dishes than on noncoated dishes. $\mathrm{CD} 200^{+} \mathrm{CD}_{34^{-}}$populations formed much more colonies than $\mathrm{CD}_{4}{ }^{+}$populations regardless of FSC values. (c) Left: evaluation of size and number of colonies formed by each cell population. Right: colony size distribution of each cell population. In both $\mathrm{CD} 200^{+} \mathrm{CD} 34^{-}$and $\mathrm{CD} 34^{+}$cells, the colony number was larger in the low FSC population than in the high FSC population. However, the $\mathrm{CD} 200^{+} \mathrm{CD} 34^{-} \mathrm{FSC} \mathrm{C}^{\text {high }}$ population formed a higher percentage of large-sized ( $>300$ pixels) colonies than the $\mathrm{CD} 200^{+}{\mathrm{CD} 34^{-} \mathrm{FSC}^{\text {low }} \text { population. CD34 }}^{+}$populations formed only small-sized colonies $(<150$ pixels), regardless of the FSC values.
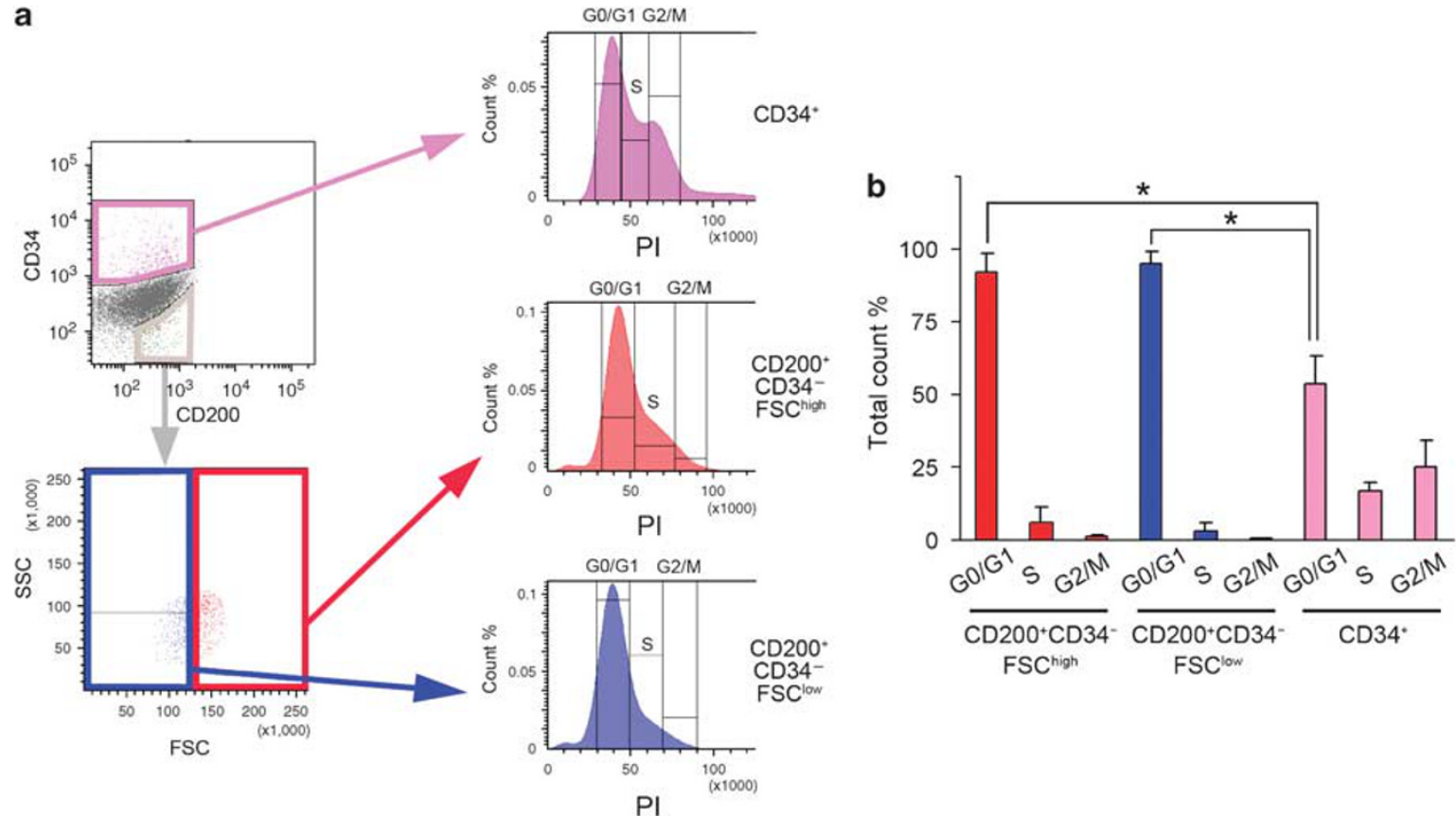

Figure 6 Analysis of cell-cycle of freshly isolated follicle-derived epithelial cells. (a) Representative data from multicolor FACS analyses of freshly isolated follicle-derived epithelial cells. Freshly isolated follicle derived cells were fractionated into CD200 ${ }^{+} \mathrm{CD} 34^{-} \mathrm{FSC} \mathrm{C}^{\text {high }}, \mathrm{CD} 200^{+} \mathrm{CD}^{-} 4^{-} \mathrm{FSC} \mathrm{C}^{\text {low }}$, and $\mathrm{CD} 34^{+}$ subpopulations. DNA contents of each subpopulation are shown in the histograms. The highest peaks of propidium iodide (PI) fluorescence were regarded as diploid cells in the $G_{0} / G_{1}$ phase, whereas tetraploid cells in the $G_{2} / M$ phase constitute the population with twice the PI intensity of diploid cells. Cells between the $G_{0} / G_{1}$ and $G_{2} / M$ cells were regarded those in the $S$ phase. (b) Proportion of each cell-cycle phase in subpopulations. CD34 ${ }^{+}$cells contain a

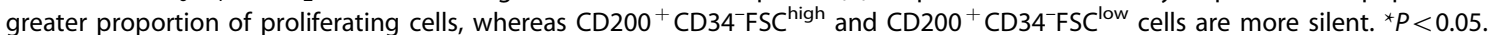

would be useful biomarkers for characterizing freshly isolated human follicular epithelial cells in diverse stages of differentiation.

Supplementary Information accompanies the paper on the Laboratory Investigation website (http://www.laboratoryinvestigation.org)

\section{ACKNOWLEDGEMENT}

This work was supported by a grant from the Japanese Ministry of Education, Culture, Sports, Science, and Technology (MEXT; grant numbers: B2-1730474 and B2-18591964).

\section{DISCLOSURE/DUALITY OF INTEREST}

The authors declare that they have no competing financial interests.

1. Cotsarelis G, Sun T-T, Lavker RM. Label-retaining cells reside in the bulge of pilosebaceous unit: implications for follicular stem cells, hair cycle, and skin carcinogenesis. Cell 1990;61:1329-1337.
2. Oshima $H$, Rochat $A$, Kedzia $C$, et al. Morphogenesis and renewal of hair follicles from adult multipotent stem cells. Cell 2001;104: 233-245.

3. Morris RJ, Potten CS. Highly persistent label-retaining cells in the hair follicles of mice and their fate following induction of anagen. J Invest Dermatol 1999;112:470-475.

4. Jones PH, Watt FM. Separation of human epidermal stem cells from transit amplifying cells on the basis of differences in integrin function and expression. Cell 1993;73:713-724.

5. Yang J-S, Lavker RM, Sun T-T. Upper human hair follicle contains a subpopulation of keratinocytes with superior in vitro proliferative potential. J Invest Dermatol 1992;102:652-659.

6. Rochat A, Kobayashi K, Barrandon Y. Location of stem cells of human hair follicles by clonal analysis. Cell 1994;76:1063-1073.

7. Akiyama M, Dale BA, Sun T-T, et al. Characterization of hair follicle bulge in human fetal skin: the human fetal bulge is a pool of undifferentiated keratinocytes. J Invest Dermatol 1995;105: 844-850.

8. Akiyama M, Smith LT, Shimizu H. Changing patterns of localization of putative stem cells in developing human hair follicles. J Invest Dermatol 2000;114:321-327. 
9. Lyle S, Christofidou-Solomidou M, Liu Y, et al. The C8/144B monoclonal antibody recognizes cytokeratin 15 and defines the location of human hair follicle stem cells. J Cell Sci 1998;111:3179-3188.

10. Rumio C, Donetti E, Imberti A, et al. c-Myc expression in human anagen hair follicles. Br J Dermatol 2000;142:1092-1099.

11. Ohyama $M$, Terunuma $A$, Tock $C L$, et al. Characterization and isolation of stem cell-enriched human hair follicle bulge cells. J Clin Invest 2006;116:249-260.

12. Liu Y, Lyle S, Yang Z, et al. Keratin 15 promoter targets putative epithelial stem cells in the hair follicle bulge. J Invest Dermatol 2003;121:963-968.

13. Wright GJ, Puklavec MJ, Willis AC, et al. Lymphoid/neuronal cell surface OX2 glycoprotein recognizes a novel receptor on macrophages implicated in the control of their function. Immunity 2000;13: 233-242.

14. Barclay AN, Wright GJ, Brooke G, et al. CD200 and membrane protein interactions in the control of myeloid cells. Trends Immunol 2002;23:285-290.

15. Trempus CS, Morris RJ, Bortner CD, et al. Enrichment for living murine keratinocytes from the hair follicle bulge with the cell surface marker CD34. J Invest Dermatol 2003;120:501-511.

16. Poblet $\mathrm{E}$, Jimenez-Acosta F, Rocamora A. QBEND/10 (anti-CD34 antibody) in external root sheath cells and follicular tumors. J Cutan Pathol 1994;21:224-228.

17. Poblet $\mathrm{E}$, Jiménez $\mathrm{F}$, Godínez JM, et al. The immunohistochemical expression of CD34 in human hair follicles: a comparative study with the bulge marker CK15. Clin Exp Dermatol 2006;31:807-812.

18. Crane JF, Trainor PA. Neural crest stem and progenitor cells. Annu Rev Cell Dev Biol 2006;22:267-286.
19. Peters EMJ, Stieglitz MG, Liezman C, et al. p75 neurotropin receptormediated signaling promotes human hair follicle regression (catagen). Am J Pathol 2006;168:221-234.

20. Maldonado-Estrada J, Menu E, Roques $P$, et al. Evaluation of cytokeratin 7 as an accurate intracellular marker with which to assess the purity of human placental villous trophoblast cells by flow cytometry. J Immunol Methods 2004;286:21-34.

21. Rheinwald JG, Green H. Formation of a keratinizing epithelium in culture by a cloned cell line derived from a teratoma. Cell 1975;6: 317-330.

22. Paus $\mathrm{R}$, Muller-Rover $\mathrm{S}$, van der Veen $\mathrm{C}$, et al. A comprehensive guide for the recognition and classification of distinct stages of hair follicle morphogenesis. J Invest Dermatol 1999;113:523-532.

23. Kloepper JE, Tiede S, Brinckmann J, et al. Immunophenotyping of the human bulge region: the quest to define useful in situ markers for human epithelial hair follicle stem cells and their niche. Exp Dermatol 2008;17:592-609.

24. Frye M, Gardner C, Li ER, et al. Evidence that Myc activation depletes the epidermal stem cell compartment by modulating adhesive interactions with the local microenvironment. Development 2003;130:2793-2808

25. Blanpain C, Lowry WE, Geoghegan A, et al. Self-renewal, multipotency, and the existence of two cell populations within an epithelial stem cell niche. Cell 2004;118:635-648.

26. Morris RJ, Liu Y, Marles L, et al. Capturing and profiling adult hair follicle stem cells. Nat Biotechnol 2004;22:411-417.

27. Barrandon $\mathrm{Y}$, Green $\mathrm{H}$. Cell size as a determinant of the cloneforming ability of human keratinocytes. Proc Natl Acad Sci USA 1985;82:5390-5394. 